\title{
HISTÓRIA ANTIGA NA ÁFRICA E A ÁfRICA NA HISTÓRIA ANTIGA
}

Luciano César Garcia Pinto ${ }^{1}$

Uma rápida busca pelo termo Africa (e seus derivados tais como o gentílico Africani etc.) na Library of Latin Texts - grande base eletrônica de textos que abrange tudo que foi escrito em latim (com exceção de inscrições parietais e epigráficas) desde Lívio Andronico (séc. III a. C.) até o Concílio do Vaticano II (término em 1965) - apresenta como resultado impressionantes três mil setecentas e oitenta e cinco sentenças em que o vocábulo e termos afins aparecem, distribuídas entre mais de duzentos e noventas autores. Ao longo dos vinte e dois séculos recobertos por essa base de dados, os três primeiros em menções são o V e o I d.C. e o I a.C. Se, no caso dos séculos I antes e depois de Cristo, está-se no momento das extensas aquisições territoriais dos exércitos de Roma, a primeira posição ocupada pelo século $\mathrm{V}$ explica-se pela intensa atividade intelectual e política do maior pensador nascido em solo africano que o mundo de fala latina conheceu: Agostinho, bispo de Hipona.

Essas poucas informações - que não levam em conta, por exemplo, possíveis menções alusivas e, portanto, não explícitas e identificáveis com uma simples busca lexical - dão apenas uma dimensão da presença constante do continente africano na história textual e cultural do mundo de fala latina. Como se entrecruzam os caminhos da história dessa presença com seu estudo em solo africano é a proposta central deste número da revista Heródoto.

Os artigos reunidos neste número da revista tentam dar conta da diversidade de temas e pesquisas no campo da relação entre o mundo antigo e o continente africano, tanto na pena de estudiosos radicados na África quanto na de pesquisadores brasileiros que se dedicam ao tema. Os trabalhos aqui publicados cobrem assuntos que vão desde temas específicos de estudo do mundo antigo e a África até o tema da presença da África antiga na sala de aula no Brasil.

${ }^{1}$ Professor Doutor - Universidade Federal de São Paulo, São Paulo, Brasil.

E-mail: lucianuscaesar@gmail.com 